\title{
MORALS, ROLES AND REASONS FOR ACTION
}

J.L.A. GARCÍA

University of Notre Dame

\section{'Morally ought' as role-relative}

Strawson has written: 1

We should think of the many different kinds of relationship which we can have with other people -as sharers of a common interest, as members of the same family, as colleagues, as friends, as lovers, as chance parties to an enormous range of transactions and encounters. Then we should think, in each of these connections in turn, and in others of the kind of importance we attach to the attitudes and intentions towards us of those who stand in these relationships to us, and of the kind of reactive attitudes and feelings to which we ourselves are prone. In general, we demand some degree of good will or regard on the part of those who stand in these relationships to us, though the forms we require it to take vary widely in different connections.

In this essay I wish to sketch out some implications of a moral theory that takes seriously the phenomena Strawson draws attention to. What $I$ have in mind in understanding one's moral life as a matter of acquitting oneself in a variety

1 P.F. Strawson, "Frcedom and Resentment," in Freedom and Resentment and Other Essays (London: Methuen, 1974), p. 6. The role-centered conception of morality is perhaps also suggested by this remark by Cavell: in "morality, one human being [A] confronts another [B] in terms of that person's [A's] position. . . [where] "in terms of that person's position" means in terms of what he is doing and must do and ought to do... [i.e.,] in terms of his [B's?] eares and commitments." S. Cavell, The Claim of Reason (Oxford: Oxford University Press, 1979), p. 325. (The variables are inserted to disambiguate the passage.) 
of different relationships in which one is involved, including some of the ones Strawson mentions (family member, friend, lover) and others as well (fellow citizen, informant, fellow human being). Thinking of these relationships as roles we play in the lives of others, we get a new slant on the categories of morality: the moral virtues are features that help make on a good $R$, the vices those that make one a bad $R$; what one (prima facie) ought to do is what one ought as an $R$ to do; your moral duties to me are the duties you have to me as my $R$, and my moral rights against you are the rights I have against you as your $R$; you treat me unjustly when you violate my rights as an $R$ against you; your act is supererogatory when it exceeds the level of concern for my welfare that is merely your duty as my $R$. As Strawson suggests, the common currency of moral life is compassion and goodwill, but different roles will call for different kinds of manifestations of that goodwill. One who undertakes to inform you acts as your informant, and as such he is to will you the special good of true belief; hence, the immorality of lying. One who makes a pledge to you thereby enters a role in which he is dutybound to secure to you the benefit promised. If I violate my duties to you as your $R$ I so alter the relationship that your goodwill toward me would naturally be lessened in an unobjectionable way, opening the door to your defensive attacks and my punishment. If I exceed my duties to you I so alter the relationship that $I$ become entitled to the special benevolence of gratitude.

This account can be expanded to cover not just the moral governance of human interpersonal dealings but also to account for the virtue and duty of piety in terms of our relationship to God, for humaneness in terms of our role as fellow creatures to brute animals, and for self-restraint and selfdevelopment in terms of the position of steward and guardian cach person occupies for himself or herself. I won't, however, be much concerned here with one's moral relationships with the Almighty or lower animals or oneself, but, like Strawson, will restrict my attention to our moral relationships with one another. 
A full exposition would need to answer a number of questions: what can be the value of $R$ ?, i.e., what are the morally-determinative roles? What makes them and not others to be morally determinative? How is a role of this sort defined? Do the morally-determinative roles vary over time and place? Such exposition, however, is not my aim in this essay. Instead, my project here is, first, to show how the role-conception of morality if developed in a certain way can give.us an understanding of moral virtue, duty, etc. more intuitively acceptable than is otherwise available and, second, to provide answers to certain hard questions which might be posed in criticism of such a conception. It seems to me that unless such a conception holds out the promise of some significant explanatory power and offers fresh approaches to troubling problems, there is little point in seeing how far it can be taken, and no interest either in developing and defending it or in refuting it and showing its weaknesses.

Consider, then, Gass' 'case of the obliging stranger': I come upon a stranger in the street, invite him into a nearby alley and, when he obliges, I club him and toss him in an oven wherein to cook him to death; Gass adds that I carelessly overcook him, thereby ruining the experiment for which I had been preparing his body.2 "Something has been done wrong. Or something wrong has been done." Indeed, both. I have done the experiment wrong, badly; behave badly as an experimenter. However, this doesn't show that something (morally) wrong has been done, although surely something wrong has been done. Gass notes, "No more convincing refutation of any ethic could be given than by showing that it approved of my baking the obliging stranger." Nor is there any trouble in isolating the main evil -it is the cooking and killing that is so objectionable.

Different moral theories will give differing accounts of what makes my action immoral. Gass thinks there is something improper in even raising this question, but his argument

2 W. Gass, "The Case of the Obliging Stranger," Philosophical Review 65 (1957), esp. pp. 193-99. 
isn't persuasive. He seems to think the moral philosopher must say:

The wrong done the obliging stranger was not the act of cooking him but was something belonging to the act in some one of many possible ways. It is not I who am evil (if I am not mad) but something which I have that is; and while, of course, I may be adjudged wicked for having whatever it is I have that is bad, it is only because I have it that I am wicked -as if I owned a vicious and unruly dog.

Now, I think the wrong done was the act of cooking him, though it is bad because of "something belonging to the act", i.e., the malevolent motive and intention it expresses. When I thus act evilly, I am evil in so acting, though again this is because of "something which I have that is [evil]", i.e., my wicked intent. The analogy between having an intention and having a dog is merely tendentious, as if 'having' always expressed the same relation. Nevertheless, I believe Gass is onto something important when he points out the blatant inadequacy of explanations philosophers standardly offer to account for the immorality of such actions. He bids us

Consider [the proposed explanations]: [1.] My act produced more pain than pleasure. [2.] Baking this fellow did not serve the greatest good to the greatest number. [3.] I acted wrongly because I could not consistently will that the maxim of my action become a universal law. [4.] God forbade me, but I paid no heed.[5.] Anyone can apprehend the property of wrongness sticking plainly to the whole affair. [6.] Decent men remark it and are moved to tears.

Of course, most of these are caricatures and some are distortions of theories about how one would come to know the act was wrong, not about what makes it wrong. Still, Gass is right to think that these accounts seem to miss the point. Though some of these proposals may account for why my behavior wrongs God, or is irrational, or is offensive to the 
community (and we can add an Epicurean or Hobbesian theory which would explain why my action is imprudent), none of them makes it clear in an adequate way just why it is the stranger who is mistreated, why, in so acting, I am bad to him! These theories don't seem to make clear how my wrongdoing consists in wronging the stranger, why he must be the focus of ethical attention here. The act is vicious, after all, in that it is malevolent and there is no trouble in saying toward whom I am malevolent - not to the greatest good or the common good or God or pure reason or my own human nature, but to the stranger.

The explanations all seem to go off the track -they try to explain why the act is wrong but can only rather indirectly explain why the moral duty violated is my duty to the stranger. At best, "the explanatory factor", as Gass puts it, "is more inscrutable than the event it explains." Mill was sensitive to this fact: ${ }^{3}$

[T] he customary morality, that which education and opinion have consecrated, is the only thing which presents itself to the mind with the feeling of being in itself obligatory; and when a person is asked to believe that this morality derives its obligation from some general principle round which custom has not thrown the same halo, the assertion is to him a paradox; the supposed corollaries seem to have a more binding force than the original theorem. . He says to himself, I feel that I am bound not to rob or murder. . . but why am I bound to promote the general happiness?

Yet not every theory of morals need so perplex the ordinary thinker. Suppose we take seriously the old saw that man is a social animal and concede that it is human nature to desire to have fellows and thus be a fellow to others. What we want from our fellow human beings is, minimally, a modicum of goodwill, i.e., of fellow feeling. Suppose further that, perhaps simply because of this, 'fellow man' (or, more neutrally, 'fel-

${ }^{3}$ J. S. Mill, Utilitarianism (Indianapolis: Bobbs-Merrill, 1957), p. 34. 
low human being') is a morally-determinative role. Being morally good/bad, virtuous/vicious, dutiful/inofficious, etc. consists in being so in such a role. Then what makes my action wrong is that the malevolent murderous intention from which it proceeds is so utterly at odds with the goodwill and fellow feeling that I ought as the stranger's fellow human being to feel and act from. In wanting and (successfully) trying to kill him my attitude towards his welfare is the polar opposite of what it would be natural for him to want from me as his fellow. This conduct makes me extraordinarily bad, bad to him, in one of my morally-determinative roles. I think such a theory as this, unlike the more familiar ones from the history of moral philosophy, leaves us rather close to what an ordinary person would be inclined to say if she seriously tried to answer the question (rather strange outside of a philosophical discussion), 'What was wrong about my conduct?' I mistreated the stranger, one is wont to say, in that my conduct was so far removed from, indeed was antipodal to, the way any normal person wants to be treated by others. I was bad because I failed, even egregiously abused, the stranger; I was bad to him, i.e., bad in my relation to him. Certain versions of the role-conception of morality thus seem to enable us to place the locus of moral service and violation in such a case where it belongs - not in the greatest good as calculated from Sidgwick's "point of view of the universe" or in the fluorishing or Pure Reason of the agent, etc., but in the interest and concern of the victim, a figure whose involvement often tends to appear peripheral in the grand theories of the philosophers, however central it may be in naive moral thinking.

According to the role-centered conception of morality, at least in some of its versions, sometimes what one morally ought to do is determined primarily by what would benefit the beneficiary/victim of the agent's behavior (the person Warnock calls the 'moral patient'). Such moral 'ought'-statements do not derive their backing from the action's promoting the agent's welfare or projects in any way. It might and it might not; the agent morally ought to do it in either case. So conceived, such moral 'ought'-statements will resemble a class 
of 'ought'-statements little attended to by philosophers. I have in mind such statements as 'Knives ought to be sharp,' 'Pens ought to make clear distinct lines', 'Watchmen ought to be alert', 'Doctors ought to care for their patients', etc. As Foot says, "the qualities by which a doctor is judged a good doctor, and a house a good house, are those which make them useful to patients and tenants respectively," and thus not necessarily those useful in advancing the desires of the doctor or, a fortiori, the house. She even speculates, "Perhaps good men are those who have qualities useful to society not to themselves; perhaps it is others who have reason to want them to be good?"4 That, of course, is close to the view I have proposed here, though the 'other' whose natural desires matter will usually be a particular individual rather than society. Moreover, the desires that serve to justify the claim that this or that quality is a good one for a (fellow) man to have also serve to justify the claim that this or that type of action is the sort a (fellow) man ought to perform.

\section{'Morally ought' and reasons for action}

However, we have now so detached what one morally ought to do from what serves the agent's interest and desires that new questions arise. First, can it be that $S$ morally ought to $F$, even though $S$ has no disposition to $F$ ? More strongly, can I think that I morally ought to $F$ even when I have no disposition to $F$ ? Second, can it be that $S$ morally ought to $F$, even though there is no reason for $S$ to $F$ ? Third, if the answer to either of these questions is affirmative, then why should one care about what one morally ought to do or to be? In the remainder of this essay I will try to answer the first two questions. The third I hope to treat at another time.

Plainly on the account offered here the answer to the first question is affirmative. Knowing what pens are for, knowing what we want from something qua pen, I know that a pen,

4 P. R. Foot, "Reasons for Action and Desires," Aristotelian Society, Supplementary Volume 46 (1972): 206-7. 
any pen, and therefore this pen, ought to make a distinct line. This pen ought to make such a line regardless of whether it has any disposition to. Indeed, if it has no disposition (tendency) to make such a line this is ground for evaluating it negatively, recognized it as a poor pen. Exactly the same sort of reasoning applies to persons in their various external roles: watchmen, doctors, friends, fellow men, etc. Some of these are morally-determinative roles and others are not, but the important point is that the fact that someone occupying such a role ought to do this or to be that is not conditional on her dispositions (preferences). A watchman ought to be alert because of what we want from watchmen and if this one is not disposed to be alert, that is just evidence that he is a poor watchman. In the same way, my friends and fellow men ought to be concerned for my well-being and one, call her Adams, who is not disposed to such concern is to that extent bad in her role. Since these are morally-determinative roles, that means that she is to that extent morally bad.

This reasoning is available not only to us but to Adams herself. She might recognize that in virtue of what people want from society my fellow human beings ought to be kind to me, might realize that she is my fellow and therefrom conclude, correctly, that she ought to be kind to me and affirm, 'I morally ought to be kind to García.' Still, for all that, she might simply loathe me and have no disposition whatever to be kind to me. Hare thinks that this would show that she wasn't using the 'I ought. ..' statement "as a value judgment' where such judgments comprise "the class of sentences containing value words which is of primary interest to the logician who studies moral language."'s Things are always evaluated relative to what is demanded or wanted from them and it need not be the evaluator's own wants that are consulted in the evaluation. I can say that this is an excellent computer because I know what users want from computers, though I don't want anything from them myself. This is not an inverted

5 R. M. Hare, Language of Morals (Oxford: Oxford University Press, 1952), pp. 168f. 
commas use of 'excellent'; it is a paradigmatic use of it. Eorrowing Kovesi's terminology, we can say that Hare is confusing evaluating, a cognitive process of measuring a thing's properties and performance against the relevant desires and purposes of those related to it in certain ways (e.g. as users), with valuing, which involves not just evaluating but also holding various favorable affective attitudes toward the thing on the basis of a positive evaluation. 6 Adams evaluated a certain course of conduct as good morally, one she ought morally to adopt, but she doesn't value such conduct -she has no favorable feelings toward it; she neither wants nor is disposed to adopt it.

This view of things puts me at odds with the prescriptivists in one of the central disputes between them and the descriptivists. For there is no logical connection, on my account, between thinking that I morally ought to $F$ and being disposed to $F$. On the other hand, I see every reason to think there is a close connection, indeed a logical one, between the facts about what one naturally wants from one's friend and what a friend ought to be and to do. So if "Logic cannot take us all the way from [1] beliefs in non-moral facts,"7 through [2] moral 'ought'-judgments, "to [3] dispositions to action," I agree with the descriptivists that a logical gap must lie between (2) and (3) and am skeptical of the prescriptivists' claim that there is such a gap between (1) and (2). ${ }^{8}$ It should be noted that Wiggins claims an 'is/ought' gap remains even after the supposed fact/value gap is closed, but he thinks of these 'ought'-statements as "decisions" and seems not to be talking about statements that one morally ought to do or to

$6 \mathrm{~J}$. Kovesi, "Valuing and Evaluating" in Jowett Papers, 1968.1969, ed. B. Y. Khanbhai, et al. (Oxford: Oxford University Press, 1970), pp. 53-64.

7 Hare, Moral Thinking (Oxford: Oxford University Press, 1981), p. 189. I sec no reason to think we can sharply distinguish moral from non-moral facts.

8 My allowing a logical gap between (2) and (3) makes me an externalist in Frankena's useful terminology to designate those who think that motivation to $F$ is not a logical condition of thinking that one morally ought to $F$. Sce W. K. Frankena, "Obligation and Motivation in Recent Moral Philosophy" in Eissays in Moral Philosophy, ed. A. I. Melden (Seattle: University of Washington Press, 1966), pp. 40-81. 
be this or that. 9 I agree that decisions cannot be logically derived from factual statements; decisions are mental episodes, acts of will, and therefore (unlike propositions or sentences) not the right sort of thing to be logically entailed. Perhaps Wiggins is using 'decision' to refer to what one has decided upon, so that when I decide to go to the store my decision is 'to go to the store.' Again, this seems ill-suited to serve as conclusion to any argument. However, all this has nothing to do with 'ought'-statements. Wiggins may be suggesting that (a) 'I thing I ought to $V$ ' means or expresses the same thing as (b) 'I have decided to $V$,' but, plainly, it doesn't. As familiar cases of akrasia attest, neither entails the other.

The second question was whether it can be true that $S$ ought to $F$ even though there is no reason for $S$ to $F$. To this the short answer is negative. Again, consider the case of implements. In virtue of what we want from knives and pens, what we use them for, knives ought to be sharp and pens ought to make distinct lines. Any sane person would greet with derision the suggestion that, despite these facts, there is no reason for a knife to be sharp and none for a pen to make distinct lines. On the contrary, these things are not at all arbitrary. There is a reason of the very best kind for them -sharp knives and pens that make distinct lines, insofar as they have these qualities, are and work better. What could be a better reason? By similar reasoning we can conclude that there is a reason for a watchman to be on the lookout for intruders and a reason for one's friends and fellows to be concerned with one's well-being. So, on the role-centered conception, there is always reason for one to do or be what morally one ought to do or be.

This short answer, however, is unsatisfactory. Recent philosophers have been concerned not so much with whether there is a reason for $S$ to do or be what $S$ morally ought to do or be as with whether $S$ has a reason to do it or be it. That is rather different. Though it is plainly right that there is a reason for

9 Sce D. Wiggins, "Truth, Invention, and the Meaning of Life," Proceedings of the British Academy 69 (1976): 331-78. 
a knife, a pen, etc. to have the qualities it ought to have, it sounds quite strange to say that a knife, pen, etc. has a reason to have them, and still more strange to say of a particular knife or pen that it has a reason to have those qualities. What then shall we say about whether what one's doctor or, more important, one's fellow man, ought as such to do she eo ipso has a reason to do? Raz and Harman have suggested that one can infer

$$
\text { (1) } S \text { has a reason to } F
$$

from

(2) There is a reason for $S$ to $F$

together with some additional premise to the effect that $S$ knows or believes or could easily find out that there is a reason, though they disagree with me about the truth conditions for (2).10 If they are right about the inference then we can explain why the knife and the pen don't have a reason to be what they ought - they can't have cognitive attitudes- but can also affirm that any well-informed person does have a reason to do and be what she morally ought. That would be pleasing. However, I doubt we can accept such an inference, for then we could conclude that someone has a reason to do something from premises that virtually ignore the agent's desires and welfare. Against this, Foot's claim that what one has reason to do must advance one's wants for well-being has considerable intuitive appeal. At least it does to me. So,

(A) when $S$ morally ought to $F$, it follows necessarily that there is a reason for $S$ to $F$,

but it seems that $S$ has a reason to $F$ only if it is to her advantage to $F$, and

$10 \mathrm{~J}$. Raz, Practical Reason and Norms (London, 1975), p. 21 ; G. Harman, "Relativistic Ethics," in Midwest Studies in Philosophy, vol. 3, ed. P. French, et al., p. 112. 
(B) moral considerations by themselves cannot guarantee that $S$ has reason to be and do what she morally ought.

Bernard Williams is unhappy with (A).11 He thinks statements of (2)'s form naturally lend themselves to an "interpretation" or use which leaves their truth independent to whether $S$ 's $F$-ing promotes any of $S$ 's aims. He calls this the "external" interpretation of these statements and suggests that one thing one might mean in making such a statement is simply that "things would be better if the agent so acted." Williams, how. ever, goes on to affirm the puzzling thesis that "there is reason to think that there are no external reasons for action" corresponding to the external interpretation of reason-statements. Williams seems to mean that (2) is never true when $S$ 's $F$-ing would not advance $S$ 's aims. I find this puzzling because he explicity states that there is an interpretation of it on which it is true in just such circumstances and even makes a sugges tion about what this interpretation is.

Williams also raises a more comprehensible objection against reason-statements externally interpreted.

There are of course many things that a speaker could say to one who is not disposed to $F$ when the speaker thinks that he should be, as that he is inconsiderate, or cruel, or selfish, or imprudent; or that things, and he, would be a lot nicer if he were so motivated. Any of these can be sensible things to say. But one who makes a great deal out of putting the criticism in the form of an external reason statement seems concerned to say that what is particularly wrong is that he is irrational.

It is this that disturbs Williams since "this suggestion, once the basis of an internal reason claim [i.e., connection to something the agent wants] has been clearly laid aside, is bluff."

11 B. Williams, "Internal and External Reasons" in Moral Luck (Cambridge: Cambridge University Press, 1981), esp. pp. 101, 110f. Also see "Ought and Moral Obligation," op. cit., p. 123. 
He concludes, "If this is so, the only real claims about reasons for action will be internal claims [i.e., reason-statements true only when the action promotes the agent's aims]." This last remark suggests that (2) is false when $S$ 's $F$-ing would not promote $S$ 's aims and, as I have said, this contradicts Williams' own admission of the external interpretation. But what is more interesting is that this doesn't follow from Williams' quite reasonable criticism that someone "who makes a great deal" of insisting that there is a reason for $S$ 's $F$-ing when $S$ morally ought to $F$ "seems concerned" to impugn not only $S$ 's morality but her rationality if she fails to $F$. I agree with Williams that one might use a reason-statement with just such criticism in mind and I also agree with him that it is mere bluff unless doing and being what one morally ought always turns out to benefit the agent or her goals. But that shows only that appeals to what there is reason to do can be used to mislead and perhaps lend themselves to such misuse; it does nothing to show that there being a reason for the agent to do something derives from what serves her wants and well-being in the way that the agent's having a reason to do something derives therefrom. One way to block the tendency of reasonstatements to mislead is to get clearer about their grounding; that is what $I$ have attempted in this section.

Harman objects to (B), my claim that moral considerations alone don't guarantee that ' $S$ has a reason to $F$ ' follows from 'S morally ought to $F$ '. To disallow such an inference, he says, "is... to distort the meaning of the moral 'ought', which "is used to speak of the things an agent has moral reasons to do." 12 He thinks that a person's reasons for action arise from the agent's goals, desires, and intentions, sometimes connected to them via the agent's acceptance of certain tacit conventions; he thinks moral 'ought'-statements have the same genesis. Harman then imagines a group of cannibals with a morality composed of conventions different from our own. (He thinks that "our morality" is composed of conventions; I think this false but won't try to show that here.) "We could not suppose

12 Harnan, op. cit., p. 111. 
that the cannibals ought not to eat human flesh unless we also supposed that they have a reason not to eat human flesh. The trouble is that we are presently assuming that they have no such reason, because their morality is not the same as ours." 13

Harman extends this to cover rebels among us who reject our 'moral conventions' as professional killers and, he supposes, Hitler do. He draws out the implications of his theory: "Any man who could have done what Hitler did must be the sort of man who would not have a reason not to do it." Though he allows us to condemn Hitler himself as a 'monster', acts of the kind he committed as 'wrong', and his conduct as something that 'ought never have happened', Harman thinks we cannot say that Hitler himself was wrong to kill the millions, or that it was wrong of him to kill them, or that he morally ought not to have killed them. "To say... 'Hitler ought morally not to have done it' would imply that Hitler accepted the relevant moral conventions. But his actions show that he does not accept" them. Likewise, "it would be a misuse of language to say of hardened professional criminals that. . . they ought morally not to kill people. Since they do not share our conventions, they have no moral reasons to refrain from killing us." In general, ' $S$ morally ought not to $F$ ', we are told, "means, roughly, that [S's not $F$-ing]. . . is in accordance with the.moral demands that 'we' accept, where 'we' includes the speaker, [the agent,]... and the intended audience, if any."14

All this seems to me wrong-headed. First, the statement at the end has the bizarre consequence that in a case where $S$ and I do, but you don't, share a morality that demands his not $F$-ing, my claim ' $S$ morally ought not to $F$ ' is true when I say it to $S$ or to myself but not when I say it to you. Second, and more important, it is difficult to see how we are to separate 'Hitler was unjust' (which Harman allows) from 'It

13 Harman, Nature of Morality (New York: Oxford University Press, 1977), p. 106. See also pp. 109, 113. Also his "Human Flourishing, Ethics and Liberty," Philosophy and Public Affairs 12 (1983): 317-20.

14 Harman, "Relativistic Ethics," p. 115. 
was unjust of Hitler to kill the millions' (which is its basis), and hard to see how we can affirm this without affirming 'It was, at least prima facie, wrong of Hitler to kill the millions' which Harman is at pains to deny. Third, that Hitler, cannibals and professional killers reject some supposed social conventions is irrelevant to the question of whether morally they ought not kill their victims from cruel or callous motives. Fourth, morally they ought not to perform such killings since such acts reflect attitudes of ill-will radically opposed to the benevolence that would make them good in their morallydeterminative roles. Fifth, the assertion that they oughtn't is no misuse of language, save in the way that speaking truisms is a waste of others' conversational time and attention, but is instead a manifest understatement whose truth should be plain. 


\section{RESUMEN}

El autor quisiera desarrollar una concepción de la vida moral como una cuestión de cumplir con los deberes que surgen de los papeles que uno tiene dentro de una gran variedad de relaciones con los demás seres humanos. Intenta mostrar que esa concepción de la moralidad en términos de papeles relacionales puede dar una explicación intuitivamente plausible de las virtudes, los deberes, etcétera. En particular, intenta mostrar que considerando la actitud de tener una buena disposición hacia cualquier otro ser humano, tal concepción puede explicar directamente el mal que se hace a la víctima de una acción moralmente errónea.

Después, usando y criticando algunas ideas de Foot, Williams y Harman, trata de elucidar la conexión que, según esa concepción, hay entre los juicios morales acerca de lo que uno debería hacer y las razones para actuar. El autor defiende una concepción 'externa' de esa conexión. 